Синишина Вікторія Михайлівна доктор педагогічних наук, доцент, доцент кафедри психології Державного вищого навчального закладу «Ужгородський національний університет», пл. Народна, 3, м. Ужгород, тел.: (095) 540-06-13, e-mail: vsinishina@ukr.net, https://orcid.org/0000-0002-7993-1638

\title{
АКМЕОЛОГІЧНИЙ ТА АКСІОЛОГІЧНИЙ ПІДХОДИ РОЗВИТКУ ОСОБИСТОСТІ МАЙБУТНІХ ПСИХОЛОГІВ
}

Анотація. У статті зроблена спроба з'ясувати можливості використання акмеологічного та аксіологічного підходів розвитку особистості майбутніх психологів в умовах вищого навчального закладу. Здійснений огляд наукових публікацій за обраною темою. Вказано, що адаптація майбутнього психолога до різних суспільних та життєвих ситуацій вимагає безперевного самовдосконалення, усвідомлення цінності своєї професії, швидкого освоєння нових інноваційних технологій, ефективного зреалізування набутих професійній умінь i навичок у діяльності. Встановлено можливості використання акмеологічного та аксіологічного підходів розвитку особистості майбутнього фахівця у вищих навчальних закладах. Визначено, що, по-перше, реалізація аксіологічного підходу сприяє становленню у майбутніх фахівців персональних цінностей, що сповна відповідають їхнім потребам, повсякденним життєвим цілям, інтересам, по-друге, орієнтація фахової підготовки майбутніх практичних психологів на «акме» спрямовує фахівця на власне вдосконалення впродовж життя, розглядає професіоналізм як вищу сходинку в розвитку особистості, скеровує на самореалізацію та розкриття творчого потенціалу під час здійснення професійних та квазіпрофесійних ролей у змодельованих ситуаціях та виконанні фахово-зорієнтованих задач. Вказано, що розвиток особистості майбутнього фахівця відбувається через усвідомлення студентами цінності професії психолога та людиновимірності майбутньої професії. 3'ясована необхідність саморозвитку, самоосвіти та рефлексії власних професійних згань, умінь та навичок. 3'ясовані можливості акмеологічного та аксіологічного підходів до розвитку особистості майбутніх психологів через застосування сучасних інтерактивних технологій. Наведено приклади розробок ділових ігор, балінт-групи та їх використання у процесі вивчення деяких фахових дисциплін.

Ключові слова: розвиток особистості, особистість майбутнього психолога, вища освіта, підготовка майбутніх фахових психологів, акмеологічний підхід, аксіологічний підхід, ділова гра, балінт-група, акме-подія. 
Synyshyna Viktoriia Mykhailivna Doctor of Pedagogical Sciences, Associate Professor, Associate Professor of the Department of Psychology of the State institution of higher education «Uzhhorod National University», Uzhhorod, Narodna Square, 3, tel.: (095) 540-06-13, e-mail: vsinishina@ukr.net, https://orcid.org/0000-0002-7993-1638

\section{ACMEOLOGICAL AND AXIOLOGICAL APPROACHES FOR THE DEVELOPMENT OF FUTURE PSYCHOLOGISTS' PERSONALITIES}

Abstract. The article deals with the trying to figure out the possibilities of using acmeological and axiological approaches for the development of future psychologists' personalities in the conditions of the institution of higher education. Review of scientific articles on the selected theme has been done. It has been indicated that the adaptation of future psychologists to different social and life situations requires continuous self-improvement, awareness of the value of their profession, fast mastering with new innovative technologies, efficacy realization of the obtained professional abilities and skills in activities. The possibilities of using acmeology and axiology in the development of future psychologist's personality in the institution of higher education have been established. It has been found that first, the implementation of the axiological approach contributes to the formation of future specialists' personal values that fully meet their needs, everyday life goals, interests, second, the orientation of vocational training of future practical psychologists to «acme» directs the specialist to his/her own improvement during whole life, examines professionalism as a higher stage in person's development, directs to self-realization and disclosure of creative potential during the implementation of professional and quasi-professional roles in simulated situations and the realization of professionally-oriented tasks. It has been stated that the development of future specialist's personality occurs through the awareness by students of the value of the profession of psychologist and the human dimension of future profession. It has been clarified the necessity of self-development, self-education and reflection of personal professional knowledge, abilities and skills. The possibilities of acmeological and axiological approaches for the development of future psychologists' personalities due to the use of modern interactive technologies have been clarified. Examples of development of business games, balint group and their use in the process of studying some professional disciplines have been given.

Keywords: development of personality, future psychologist's personality, higher education, training of future professional psychologists, acmeological approach, axiological approach, business game, balint group, acme event.

Постановка проблеми. Нині у громадянському суспільстві зростає потреба у фахівцях-психологах, котрі до професійної діяльності підходять творчо, компетентнісно та креативно й учиняють відповідно до сформованих цінностей власної професії та усвідомлення важливості саморозвитку й самоосвіти. Повсякчас зростають вимоги стосовно підготовленості психологів до фахового 
практикування в нових умовах. Адаптація майбутнього психолога до різних суспільних та життєвих ситуацій вимагає безперевного самовдосконалення , усвідомлення цінності своєї професії, швидкого освоєння нових інноваційних технологій, підвищення професійної кваліфікації та ефективного зреалізування набутих професійній умінь і навичок у діяльності.

Система вищої освіти України в цілому забезпечує компетентнісне формування у психологів високого рівня фахової підготовки, що направлена на індивідуалізацію, гуманізацію і гуманітаризацію навчання, а також на саморозвиток та самореалізацію майбутніх психологів. Створення відповідних психологічних та дидактичних умов у системі вищої освіти сприяє формуванню професійно значущих якостей майбутніх фахівців, цінностей, розвиває в них творчий потенціал, активну соціальну позицію, творчі здатності. Актуальність та доцільність вивчення даної проблеми зумовили вибір теми статті, що спрямована на вивчення психологічних умов формування та розвитку особистості майбутніх фахівців-психологів, оскільки наразі виникла потреба у створенні цілісної психологічної моделі становлення особистості професіонала у сфері прикладної психології на засадах нових концептуальних підходів.

Аналіз останніх досліджень і публікацій. Важливі аспекти формування та розвитку особистості майбутнього психолога нині доволі широко досліджуються науковцями. Сучасні науковці професійну підготовку практичних психологів розглядають в руслі професійного мислення (С. Максименко, В. Панок), професійної креативності та творчого потенціалу особистості майбутнього психолога-практика (В. Моляко, С. Шандрук), розвитку загальної та психологічної культури (В. Моргун, В. Рибалка) та ін.

Науковці О. Затворнюк та О. Матвієнко професійну підготовку практичного психолога трактують як процес прогресивних особистісних змін, що чиняться в процесі соціального та професійно-діяльнісного впливу, власної дієвої активності в набутті професійних умінь і навичок [1, с. 216].

3 огляду на дослідження, загалом психологічна освіта спрямовується на забезпечення умов для усвідомлення майбутніми фахівцями світоглядних основ власної діяльності, відповідності власної фахової діяльності культурним реаліям (нормам, законам, установкам) того суспільства, до якого належить людина, що приймає психологічну допомогу. Серед досліджень слід виділити ті небагаточисельні надбання, які розкривають акмеологічні та аксіологічні концептуальні підходи та аспекти до розвитку особистості психолога в умовах вищого навчального закладу. Акмеологічний та аксіологічний аспекти розвитку особистості психолога розглядаються як теорія вищих досягнень розвитковості людини і цивілізації, розвитку особистісних здібностей та їх впливу на продуктивну діяльнісну практику в усіх сферах життєдіяльності (I. Бех, В. Василенко, О. Дробницький, А. Здравомислов, Н. Кузьміна, С. Максименко, В. Панок, Н. Пов'якель, В. Шахов, О. Шестопалюк, М. Шпак, Н. Чепелєва, Т. Яценко). 
Позаяк ці підходи ще систематизовані і розроблені не в повному обсязі, їх вивчення $\epsilon$ актуальним напрямком досліджень щодо вирішення завдань використання здобутків аксіології та акмеології до підготовки фахівців вищих навчальних закладів.

Мета статті - полягає в обгрунтуванні теоретичних та практичних основ акмеологічного та аксіологічного аспектів розвитку особистості майбутнього психолога в умовах вищого навчального закладу.

Виклад основного матеріалу. Динамічний розвиток соціальних взаємозв'язків, поглиблення суспільних та соціокультурних змін, заміна узвичаєних цінностей, моральних і духовних орієнтирів є причиною того, що нині актуалізується професійна діяльність практичних психологів у суспільстві.

Якщо сутність класичної парадигми освіти визначається результативною підготовкою практичного психолога до життя та професійної діяльності, то за некласичною парадигмою основна місія освіти полягає в забезпеченні умов для самовизначення і самореалізації особистості фахівця, де сам індивід є складно структурованою системою. Виходячи iз зазначених парадигм традиційне навчання в закладах вищої освіти є головним чином дидактично спрощеним змістом відповідних наукових дисциплін. Проте за нинішніх умов розвитку громадянського суспільства провідним завданням вищої школи $\epsilon$ розвиток здатності особистості компетентно виконувати професійні функції, результативно вирішувати проблеми і завдання; опановувати професійні якості та загальнолюдські цінності, бути здатним до саморозвитку та самоосвіти тощо. У рамках нашого дослідження виникнення і розвиток значущих особистісних новоутворень майбутнього фахівця-психолога формується за наступними парадигмами: акмеологічною, що дозволяє інтегрувати розвиток та саморозвиток особистості майбутнього фахівця в професійні знання, вміння та навички; аксіологічною, згідно 3 якою процес набуття знань поєднується 3 системою ціннісних орієнтацій майбутнього психолога щодо професійної діяльності.

Аксіологічний підхід направляє освітню діяльність майбутніх психологів на ціннісно-усвідомлене сприйняття себе як фахівця в громадянському суспільстві, затребуваній професії, поведінкових особистісних реакціях. Реалізація аксіологічного підходу сприяє становленню у майбутніх випускників персональних цінностей, що сповна відповідають їхнім потребам, повсякденним життєвим цілям, інтересам [2, с. 12].

Аксіологічний підхід дає змогу орієнтуватися на підготовку професійно компетентних майбутніх практичних психологів та пов'язаний 3 професійною поведінкою $з$ урахуванням мотиваційно-аксіологічної сфери особистості, що охоплює ключові професійні мотиви; цінності саморозвитку, престижності, професійного спілкування; психологічні інтереси в пізнанні прогресивних технологій психологічної практики. Окреслений аспект розкриває внутрішню мотивацію та ціннісне ставлення майбутніх психологів не лише до психологічної 
практики як професійної діяльності, а й до міжособистісного та професійного спілкування, до встановлення тісних дружніх контактів 3 клієнтами. Відтак, окреслений аспект дає змогу оцінювати професійну компетентність з позиції не лише мотивів, а й вольових характеристик майбутнього фахівця.

Аксіологічний підхід до розвитку особистості майбутнього фахівцяпсихолога включає:

1) ставлення до професії практичного психолога як до цінності;

2) наявність професійних мотивів;

3) професійну спрямованість студентів на саморозвиток та самостійну навчально-професійну діяльність.

Низький рівень сформованості пріоритетних цінностей характеризується відсутністю аксіологічного інтересу, студенти мають поверхневі знання, недостатньо уявляють себе в ролі психолога. Студенти не впевнені у собі, їм властиве пасивне ставлення до майбутньої професійної діяльності, вони не мають сформованого професійного ідеалу та мають значні труднощі у формуванні потреби самовдосконалення. Високий рівень сформованості пріоритетних цінностей характеризує стійкий інтерес до цінностей, у студентів сформована система аксіологічних знань, притаманне позитивне ставлення до професійної діяльності, вони реально оцінюють свої можливості і потребують самовдосконалення.

Вищевказане підтверджує думку, що в умовах вищого навчального закладу існує необхідність зреалізовувати аксіологічний аспект до формування і розвитку особистості майбутнього психолога. В умовах вищого навчального закладу уможливлюється цей процес у процесі вивчення спеціальних навчальних дисциплін, де постійно актуалізуються питання, що пов'язані із впровадженням інноваційно-інтерактивних технологій у систему освітньої підготовки майбутніх психологів. Саме тому унеобхіднюється проведення, наприклад, такої технології як ділова гра, яка спричинює такі умови навчання, котрі сповна забезпечують у студентів активну внутрішню мотивацію через усвідомлення цінності своєї майбутньої професії та направлені на власну самоактуалізацію та самореалізацію особистості.

Метод «Ділова гра» направлений на імітаційне моделювання навчальних професійних ситуацій, виконання типових фахових функцій і прийняття рішень 3 вирішення проблемних ситуаційних завдань. Ділова гра, як інтерактивний засіб, спрямовує освітню діяльність майбутнього психолога на актуалізацію, застосування і закріплення теоретичних знань та розвиває у нього дієве практикозорієнтоване мислення [3, с. 238-243.].

Результативний ефект досягається шляхом паритетної взаємодії учасників гри в спроектованій конкретній ситуації. Ділова гра в режимі діалогічного спілкування формує в студентів цілісне бачення майбутньої професійної діяльності та ii динамічного розвитку, обгрунтовує методологію подолання складних проблемних завдань, мотивує емоційно-ціннісне зацікавлення освітнім 
процесом, забезпечує оволодіння умінь щодо виконання спеціальних практикозорієнтованих функцій та ін.

Структура ділової гри складається з таких компонентів:

- спонукального, що виявляється в учасників гри у потребах, мотивах, інтересах, прагненнях та бажанні брати в ній активну участь;

- орієнтувального, який розкривається шляхом правильного відбору викладачем засобів і способів ігрової діяльності;

- виконавчого, що уможливлює реалізацію ігрової мети шляхом застосування результативно-дієвих вчинків, правильно обгрунтованих власних дій, операцій тощо;

- контрольно-оцінного, котрий спрямований на коректування та стимулювання паритетної активності в ігровій діяльності [4].

Для прикладу наведемо інтерактивну ділову гру «Життєві та професійні цінності: моя власна позиція». Таку гру можна застосовувати під час вивчення магістрами дисципліни «Психологія та педагогіка вищої школи».Мета ділової гри: навчити майбутніх психологів визначати особистісні життєві і професійні цінності на певному етапі впровадження інтерактивної педагогічної технології та цілісно структурувати їх у цінності практичної психології як професійної діяльності й інтенсивно активізувати участь студентів у груповій роботі.

Алгоритм проведення ділової гри:

- студенти розподіляються на підгрупи по 4-5 осіб, утворюючи чотири групи: «позитивні життєві цінності», «негативні життєві цінності», «позитивні професійні цінності», «негативні професійні цінності». Після обрання кожною групою «лідера-спікера» та «фіксатора» отримують від викладача завдання із заданою позицією. Членам груп надається можливість обговорити свої позиції та ідентифікувати себе з ними;

- дискусія між підгрупами по визначенні позитивних і негативних життєвих та професійних цінностей. Під час гри учасники обговорюють проблеми i труднощі, висунуті спочатку підгрупою «негативні життєві цінності», а потім підгрупою «негативні професійні цінності»: низький рівень престижності професії та вищої освіти; відсутність в освітньому процесі диференціації за рівнями навчальних досягнень студентів; низька освітня мотивація до освоєння життєвими та професійними цінностями; незнання того, де можна сповна проявити набуті під час навчання цінності, неможливість визначення того, що за їхньою допомогою вже досягнуто та ін. Підгрупи «позитивні життєві цінності» та «позитивні професійні цінності» впродовж двох хвилин шукають свій аргумент й кожна пропонує свій напрям-шлях розв’язання озвучених проблем;

- виступи «фіксаторів» по підведенню підсумків дискусії. Після дискусії «фіксатори» зачитують по черзі всі негативні життєві цінності, позитивні життєві цінності, негативні професійні цінності та позитивні професійні цінності;

- робота в підгрупах над створенням проекту рішення ділової гри 3 урахування детального обговорення виступів «фіксаторів»; 
- обговорення в підгрупах проекту рішення та виокремлення основних положень за темою ділової гри. Загальний проект рішення розробляється всередині групи представниками кожної 3 підгруп, де в спільному пошуку учасники гри віднаходять більш об’єктивно-дієве рішення в порівнянні 3 рішеннями кожної з підгруп.

- підведення підсумків гри. Викладач, підводячи підсумки ділової гри, акцентує увагу на тому, що майбутні практичні психологи в процесі гри переживають різні соціально-психологічні стани: від обвинувачуваного, захисника до футуролога i найважливіше, що всі студенти академічної групи безпосередньо приймають активну участь у відшуканні способів розв'язання професійно-спрямованих проблемних завдань.

У процесі ділової гри майбутні фахівці вчаться визначати особистісні життєві цінності та з'ясовують сутність їхнього впливу на професійну діяльність. Проте важливо пам'ятати, що в даного методу є набагато більше переваг, ніж недоліків. До переваг належить: залучення всіх майбутніх практичних психологів до творчо-мисленнєвої діяльності, стимулювання їх до результативного комунікування, формування критичного обдумування, вміння слухати, висловлювати та аргументувати особисті думки. Завдяки суб’єктній активності розвиваються такі важливі компетентнісно-діяльнісні якості особистості як професійна індивідуальність, працездатність, людинолюбство, творчість, гуманність, ініціативність, конкурентоспроможність та ін. Набуття цих якостей безпосередньо залежать від результативно отриманих знань про поведінковофахові особливості індивіда, професійні цінності та етику; здобутих навичок щодо аналізу конкретної ситуації та об'єктивної оцінки власної діяльності; особистісної підтримки загальнолюдських цінностей, які характерні для даної професії; усвідомленого прийняття відповідальності за власні професійні дії та вчинки; особистісного налаштування на складні професійні умови діяльності в процесі розв'язання важливих психологічних практично-спрямованих проблем та ін. [5, с. 142-144].

Аксіологічний аспект розвитку особистості майбутніх психологів реалізується в тісному взаємозв'язку 3 акмеологічним аспектом, позаяк професійне зростання ототожнюється 3 ціннісною сферою самопізнання, саморозвитку, самоактуалізації тощо. У нинішніх дослідженнях науковців [6;7] акмеологічний підхід відображено як вчення про вищі досягнення в розвитку людини.

У межах акмеологічного підходу, як зазначає О. Антонова, у професійній підготовці істотно змінюються акценти в бік визначення перспектив та результатів здійснення фахової діяльності шляхом встановлення спеціальної професійної придатності, психологічної готовності до практикування та меж соціальної відповідальності за процес і наслідки власної роботи [8, с. 37-38].

Орієнтація фахової підготовки майбутніх практичних психологів на «акме» направляє фахівця на власне вдосконалення впродовж життя, розглядає 
професіоналізм як вищу сходинку в розвитку особистості, скеровує на «вершини» самореалізації та творчого потенціалу під час здійснення професійних ролей у змодельованих ситуаціях та виконанні фахово-зорієнтованих задач. Стосовно застосування акмеологічного підходу психолог повинен вміти, передусім, застосовувати щодо себе: - виявлення здібностей; - пошук шляхів їхнього розвитку і можливостей застосування; - задіяння відповідних здібностям видів діяльності; - формування належної мотивації досягнень; - постановку адекватних професійних цілей; - розробку шляхів досягнення бажаного; максимально повне використання здібностей, орієнтація на досягнення успіху, як у професійній діяльності, так і у житті загалом і ін.

Проте, крім розкриття та примноження власного потенціалу акмеологічний підхід передбачає застосування набутих знань і в професійній роботі з клієнтами. Відповідно, практичний психолог повинен вміти застосувати щодо своїх потенційних клієнтів: - виявлення і розкриття їхніх здібностей; - пошук шляхів їхнього розвитку і застосування; - вибір відповідних здібностям видів діяльності; - актуалізацію та розвиток необхідних інтересів і схильностей; - формування мотивації досягнень; - постановку й актуалізацію цілей; - розробку шляхів досягнення мети; - формулювання завдань, що відповідають поставленим цілям; - розробку способів виконання завдань; - розвиток їхніх здібностей; - орієнтацію на відповідні здібностям види діяльності; - спрямування на шлях максимально повного використання здібностей, тобто на досягнення успіху, як у професійній діяльності, так і у житті загалом тощо [9].

Як відзначає О. В. Лівшун, справжній професіоналізм неможливий без розвитку загальних здібностей людини, формування системи особистісних цінностей. моральної зрілості, наявності внутрішньої мотивації діяльності. Відповідно, одне із головних завдань акмеології - з'ясувати технологію оволодіння професією на високому рівні, знайти алгоритм діяльності, який приведе до формування індивідуального стилю та високого рівня професійної компетентності. Фахівець своєї справи вирізняється постійним прагненням до самовдосконалення, професійного зростання, отже акмеологія вирішує проблему розвитку професійних здібностей і дозволяє по-новому подивитися на управління цим процесом [10, с. 80$]$.

Отже, для інтенсифікації процесу засвоєння психологічних знань, умінь, навичок потенційні консультанти, майбутні практичні психологи повині відійти від позиції пасивного об'єкта навчання. Майбутній практичний психолог повинен стати активним суб'єктом, включеним у систему інтерактивних методів навчання, що, безумовно, визначає сучасні підходи в навчанні конкурентноздатних майбутніх фахівців [11, с.108].

Вищевказане вказує на те, що в умовах вищого навчального закладу унеобхіднюється зреалізовувати акмеологічний аспект формування і розвитку особистості майбутнього психолога. Уможливлюється це із впровадженням інноваційно-інтерактивних технологій, завдяки яким моделюються ситуації, що 
виникають у реальній професійній практиці психологічної допомоги клієнтам. Якнайкраще це демонструє метод симуляції, оскільки він моделює реальну професійну ситуацію і надає студентам змогу вдосконалити знання, виробити та розвинути навички у сфері консультативної допомоги. Метод перш за все орієнтований на розвиток особистості студента і враховує його знання, інтереси, потреби і досвід. Метод симуляції дає студентам можливість спробувати себе у різних ролях, виконуючі завдання, що стосуються їх майбутньої професійної діяльності. Цей метод характеризується поглибленням зацікавленості студентів, що формує мотивацію до отримання оптимальних результатів.

Так, науковці Perez, Yuddy акцентують увагу на методі симуляції, що використовується як ефективний спосіб підключення студентів до реальних сценаріїв i задач. Симуляції використовуються для розвитку компетенцій за допомогою автентичних завдань. Симуляції зазвичай працюють для розвитку професійних компетенцій, пов'язаних із галуззю навчання. Perez, Yuddy пропонують систему Global Simulation, де весь курс навчання перетворюється в симулятивний світ, в якому студенти беруть на себе реальні ролі і обов'язки. Цей тип симуляції дозволяє студентам розвивати як коммунікатівні, так і професійні компетенції в змістовному навчальному середовищі. У дослідженні Perez, Yuddy визначено, що при опитуванні студентів, студенти знайшли моделювання релевантним. Окрім того, вони підкреслюють розвиток професійних компетенцій i переваг цього методу над традиційним, орієнтованим на викладача підходом [12].

Охарактеризуємо особливості ділової гри як технології симулятивного навчання. Ділова гра - виконання студентами різних ролей, які значущі для них бдуть у професійній сфері. Зміст гри полягає в тому, що студент «грає» роль, використовуючи поведінкові паттерни та моделі, які, на його думку, найкраще відповідають їй. У рамках ділових ігор відпрацьовуються когнітивні, поведінкові, емоційні паттерни у змодельованих ситуаціях. 3 цією метою моделюється складна ситуація, в ході програвання якої важливий сам процес взаємодії учасників. Учасники гри спілкуються мовою імітації, але студенти повинні усвідомлювати, що саме вони повинні виконувати як гравці, а що - як професіонали.Тобто сюжет гри, наприклад, може бути ігровий, а виконувані ролі - завжди є професійними.

Доцільно навести приклад ділової гри «Консультування клієнта 3 суїцидальними намірами», яку ми застосовували у процесі вивчення дисципліни «Психологія суцидальної поведінки» магістрами-психологами.

Мета ділової гри: набути практичних умінь під час проведення консультативної роботи з суїцидальним клієнтом, вміти зрозуміти проблему, що провокує суїцидальний намір із подальшим обговоренням випадку на балінтовій групі.

Рекомендації до виконання: ділова гра демонструється у парах, де студенти виконують ролі клієнт-психолог. Банк консультативних запитів повинен бути

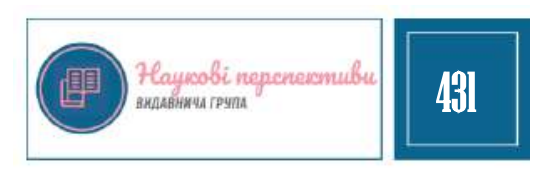


розроблений викладачем. Завдання: продемонструвати у діловій грі (у парах) взаємодію клієнт - психолог.

Доцільно навести приклад одного 3 етапів проведеного студентом консультування (в ролі консультанта та клієнта були студенти-магістри).

До психолога звернулися батьки дівчинки 12 років, яка постійно знаходиться у пригніченому настрої, оскільки в сім'ї народилася сестричка і дівчинка після народження сестрички «сховалася» у собі, весь час проводить за комп’ютером, ні 3 ким не розмовляє. На консультації говорить, що краще не жити, чим перебувати у такій ситуації.

Консультант: Ти б хотіла щось змінити у своєму житті?

Клієнт: Так.

Консультант: А що саме?

Клієнт: Не знаю.

Консультант: А чи можеш ти намалювати своє життя до народження сестрички?

Клієнт: Так.

Клієнт: Малює жовту яскраву квіточку.

Консультант: А що сталося з цією квіточкою після народження сестрички?

Клієнт: Малює засохшу квіточку з опущеною голівкою.

Консультант: Що значать ці зміни у зовнішності квіточки.

Клієнт: Раніше мене любили і я була щаслива. Ми ходили на прогулянки, ходили в кіно, їздили на море. Зараз мене не люблять, ми менше проводими разом вільний час, всі стомлені і не мають часу для мене, єдине, для чого я потрібна, так це сидіти вдома з сестрою і розважати іiі.

Консультант: А якщо ти будеш впевнена, що тебе люблять як і раніше, квіточка зацвіте знову?

Клієнт: Думаю, так.

Консультант: Якщо тебе любили раніше, як ти думаєш, чи можна так швидко розлюбити? Ось уяви, що ти любиш собачку всім сердем і у тебе з'явилась ще маленька кішечка, чи зможеш ти розлюбити свою собачку?

Клієнт: Думаю, ні

Консультант: Але кішечка маленька і потребує уваги, ти починаєш піклуватися про неї більше, ніж про собачку, приділяєш їй більше часу, бо ти розумієш, що вона не здатна ще нічого для себе зробити, забезпечити себе їжею, водою - вона помре без допомоги.

Клієнт: Так, розумію.

Консультант: То чи ти розлюбила собачку, приділяючи більше часу кішечці?

Клієнт: Ні, я люблю тварин однаково.

Консультант: Чи не нагадує це тобі ситуацію з сестрою?

Клієнт: Так.

Консультант: А що буде, коли кішка виросте, буде дорослою ?

Клієнт: Я буду гуляти з тваринами, тренувати їх. 
Консультант: Але ж для цього і до цього потрібно вкласти великі сили і час,чи не так?

Клієнт: Так.

Консультант: Ти сама б впоралася, чи попросиш допомоги у батьків?

Клієнт: Сама не впораюсь, томущо потрібно ходити в школу і на тренування. Попрошу допомоги у мами.

Консультант: I як ти гадаєш, мама відмовить?

Клієнт: Ні, ніколи.

Консультант: А якби у тебе попросила допомогу мама, ти б відмовила?

Клієнт: Думаю тепер, що ні.

Консультант: Отже, ти казала, що тобі батьки не приділяють час, оскільки не люблять тебе. Давай спробуємо скласти список можливих варіантів причин, чому батьки, як ти вважаєш, приділяють тобі менше уваги, можливо, є ще причини, окрім «нелюбові»?

Клієнт: (пише і проговорює вголос). Можливо, це пов'язано 3 тим, що вони...Ще, можливо, вони...

Консультант: Твій список помітно змінився, була одна причина, тепер 3'явилось більше. Що ти думаєш з цього приводу?

Клієнт: Напевно, я піддалася емоціям у той момент. Зараз я розумію, що, можливо, існують й інші причини. Так, звичайно, мене не могли розлюбити, найімовірніше, моя думка пов'язана з моїми хибними підозрами.

Консультант: Як почувається твоя квіточка?

Клієнт: Починає оживати...

Після рольових ігор студентам можна запропонувати створити балінтове коло. Балінт-групи - технологія колегіально-професійної взаємодії, результатом якої є набуття нових знань, рефлексія вмінь, навичок щодо власного навчальнопрофесійного та квазіпрофесійного досвіду. Водночас, це і акме-подія, яка дає можливість професійного та особистісного зростання на основі ознайомлення 3 методами і техніками роботи, підходами колег (в данному випадку студентів) до вирішення подібних психологічних запитів клієнтів.

Група Балінта дає змогу екологічно опрацювати негативні емоції, що можуть виникти в процесі квазіпрофесійної діяльності, яка імітує професійну діяльність, а також можливість отримати колегіальну підтримку, повірити у свої професійні здібності. Наводимо приклад балінтового кола, що сторювалося студентамимагістрантами після виконання ділових ігор.

Мета балінтового кола: рефлексувати власні професійні знання та вміння, рефлексувати емоційні стани під час консультативної роботи у рольовій грі клієнт-психолог.

Рекомендації до виконання: у балінтовому колі приймають участь студенти групи, які на практичному занятті були учасниками рольових ігор (квазіпрофесійних ситуацій) та проводили консультування чи були свідками консультативної роботи. 
Перше коло: коло почуттів.

Учасники групи висловлювали свої почуття і стани, з якими прийшли на балінтове коло. Озвучувалися такі метафоричні назви емоцій як вичавлений лимон, пружина, залізний спокій, груз та перевантаження, чи гарний настрій, переповнення, задоволення, віра у себе.

Друге коло: вибір протагоніста (учасника, який пред’являв випадок). Обрали консультанта, який консультував дівчинку 12 років з суїцидальними проявами.

Третє коло: пред'явлення запиту.

Студент-консультант сказав, що не може заспокоїтися після розмови 3 клієнтом, вважає, що не вистачає вмінь стосовно консультування, соромно за виникнення моментів ступору і невміння стрімко продовжити бесіду. Весь день думає про те, як важко працювати з подібними проблемами, оскільки у самого була такаж історія з братом у дитинстві.

Ведучий: Що хотіли би отримати від групи?

Консультант: Хочу розібратися зі своїми емоціями. Чи це нормально, так почуватися?

Четверте коло: почуття, які виникли при слуханні випадку.

Група називала свої почуття: шторм, сильний вітер, неспокій, потік, буревій.

П'яте коло: запитання на уточнення (для прояснення ситуації, образу клієнта).

Група питала про те, чи була проведена психологічна консультація 3 батьками дівчинки, чи планується групова консультація із членами сім’ї дівчинки тощо.

Шосте коло: проблема консультанта.

Ведучий: Яка проблема є у консультанта, якщо він виносить цей випадок на розгляд?

Група висказала припущення про ймовірну «Ідентифікацію 3 клієнтом», співпричетність до проблеми, яку переживає клієнт. Також були думки щодо ретравматизації консультанта, оскільки він переживав у власній життєвій історії таку ж проблему.

Сьоме коло: аналогічна проблема.

Члени групи пропонують своє бачення ситуації консультанта. Члени групи радять консультанту пройти власну терапію для нівелювання ретравматизації i виникнення вторинної травми.

Восьме коло: зворотний зв'язок від того, хто представляє випадок.

Ведучий: Що Ви можете сказати зараз як консультант? Як себе почуваєте? Чи допомогла Вам ця робота? Що саме допомогло?

Висновок консультанта, випадок якого обговорювався на балінтовій групі:

Таке обговорення ситуацій дало психологічну підтримку, зняло напругу. Те, що здавалось унікальним, можливо, навіть визивало сором щодо відсутності професійних навичок, у балінтовій групі відкоригувалося підтримкою колегстудентів та відкритістю взаємодії. 
Отже, балінтове коло складає у студентів уявлення про себе як професіоналів. Відбувається розуміння, що одним із чинників успішної майбутньої професійної діяльності є особистісний чинник: а саме рефлексивні усвідомлення власних професійних знань, вмінь і навичок. Данна технологія $\epsilon$ акме-подією, оскільки формує у студентів віру у власні сили, стимулює мотивацію до особистісного та професійного зростання.

Висновки. Аксіологічний та акмеологічний підхід розвитку особистості майбутніх психологів враховує специфіку та особливості професії психолога, іiі спрямованість на надання психологічної допомоги іншим в тому сенсі, що основним інструментом діяльності психолога, окрім спеціальних психологічних методик та технік, має виступати зріла особистість психолога зі сформованими життєвими i особистісними цінностями, та бажанням до безперервного самовдосконалення і саморозвитку. Проведене дослідження дає підстави зробити наступні висновки. Акмеологічний та аксіологічний підхід до формування особистості майбутніх психологів може забезпечуватися сучасними технологіями, які дають змогу студентам зрозуміти та усвідомити необхідність як професійного, так i особистісного розвитку та зростання, передбачають орієнтацію на суб'єкт-суб'єктну взаємодію, уможливлюють визнання цінності кожного студента, створення толерантних умов для взаємодії. В той же час акмеологічний та аксіологічний підходи розвитку особистості майбутнього фахівця сприяють зреалізуванню принципу людино вимірності освіти та впровадженню гумністичних загальнолюдських цінностей в особистісні позиції студентів. Акмеологічний та аксіологічний підходи до розвитку особистості майбутнього фахівця підвищують професійну компетентність, оскільки дозволяють продуктивніше та ефективніше вирішувати запити, які ставлять перед майбутніми психологами клієнти, громадянське суспільство.

Подальше дослідження може бути спрямоване на вивчення інших важливих наукових підходів та аспектів щодо розв'язання проблеми формування та розвитку особистості психолога в умовах реформування та оптимізації професійної психологічної освіти в напрямку іiі гуманітаризації та гуманізації, особистісної зорієнтованості, що насамперед виявляється в наданні переваги особистісному розвитку перед дещо вузько спрямованим професійним.

\section{Лimepamypa:}

1. Матвієнко О. В., Затворнюк О. М. Професійна підготовка майбутніх психологів як психолого-педагогічна проблема. Науковий вісник Херсонського державного університету. 2014. Вип. 1 (1). С. 215-220.

2. Євтодюк А. В. Аксіологічні засади сучасної системи освіти України. Педагогічний пошук. 2014. Вип. 2. С. 12-15.

3. Хлєбнікова Т. М. Дидактичні ігри як метод активізації навчально-пізнавальної діяльності студентів. «Управлінські та психологічні аспекти професійної підготовки фахівців в умовах інноваційного розвитку освіти»: матеріали Всеукр. наук.-практ. конф. (Харків, 13 жовтня, 2016 р.). Харків : Планета-Принт, 2016. Ч. 1. С. 238-243. 
4. Хлєбнікова Т. М. Ділова гра як метод активного навчання педагога : навч.-метод. посібник. Х. : Основа, 2002. 80 с.

5. Аветісян Т. В. Особливості професійного становлення фахівців із соціальної роботи. SOCIOПPOCTIP: міждисциплінар. зб. наук. пр. з соціології та соціальної роботи. 2011. № 2. C. $142-147$.

6. Гавриляк I. С. Розвиток ідей фундаменталізації змісту професійної освіти: аксіологічний підхід (кінець XX - початок XXI століття): автореф. дис. ... канд. пед. наук: 13.00.01 / Черкаський нац. ун-т ім. Б. Хмельницького. Черкаси, 2014. 20 с.

7. Свтодюк А. В. Аксіологічні засади сучасної системи освіти України. Педагогічний пошук. 2014. Вип. 2. С. 12-15.

8. Антонова О. Є. Акмеологічний підхід до визначення сутності обдарованості. Проблеми освіти. 2015. Вип. 84. С. 36-40.

9. Вінтюк. Ю.В. Підготовка майбутніх фахових психологів: акмеологічий підхід. Молодий вчений. 2017. № 7. С. 267-271

10. Лівшун О. В. Акмеологічні особливості професійної готовності майбутнього вчителя. Педагогічні науки: зб. наук. праць. 2009.Ч.2. С. 79-81.

11. Асеев В. Г. Мотивация учебной деятельности и формирование личности. Москва.: Академия, 2010. $150 \mathrm{c.}$

12. Perez, Yuddy. Making Language Real: Developing Communicative and Professional Competences Through Global Simulation. Paige SIMULATION \& GAMING, 2019, p. 725-753.

\section{References:}

1. Matviienko, O.V. \& Zatvorniuk O.M. (2014). Profesiina pidhotovka maibutnikh psykholohiv yak psykholoho-pedahohichna problema [Vocational training of future psychologists as psychological and pedagogical problem]. Naukovyi visnyk Khersonskoho derzhavnoho universytetuScientific Bulletin of Kherson State University, issue 1 (1), 215-220 [in Ukrainian].

2. Yevtodiuk, A.V. (2014). Aksiolohichni zasady suchasnoi systemy osvity Ukrainy [Axiological principles of the modern education system of Ukraine]. Pedahohichnyi poshuk Pedagogical search, issue 2, 12-15 [in Ukrainian].

3. Khliebnikova, T.M. (2016). Dydaktychni ihry yak metod aktyvizatsii navchalnopiznavalnoi diialnosti studentiv [Didactic games as a method of learning and cognitive activity of students]. Upravlinski ta psykholohichni aspekty profesiinoi pidhotovky fakhivtsiv $v$ umovakh innovatsiinoho rozvytku osvity - Management and psychological aspects of vocational training in the conditions of innovative development of education: proceedings of the All-Ukrainian scientific and practical conference (part 1), (pp. 238-243). Kharkiv: Planeta-Prynt [in Ukrainian].

4. Khliebnikova, T.M. (2002). Dilova hra yak metod aktyvnoho navchannia pedahoha [Business game as a method of active teacher training]. Kharkiv: Osnova [in Ukrainian].

5. Avetisian, T.V. (2011). Osoblyvosti profesiinoho stanovlennia fakhivtsiv iz sotsialnoi roboty [Peculiarities of professional development of social work specialists]. ScioProstir SocioSpace, 2, 142-147 [in Ukrainian].

6. Havryliak, I.S. (2014). Rozvytok idei fundamentalizatsii zmistu profesiinoi osvity: aksiolohichnyi pidkhid (kinets XX - pochatok XXI stolittia) [Development of ideas of fundamentalization of the content of vocational education: axiological approach (end of XX beginning of XXI century)]. Extended abstract of candidate's thesis. Cherkasy [in Ukrainian].

7. Yevtodiuk, A.V. (2014). Aksiolohichni zasady suchasnoi systemy osvity Ukrainy [Axiological principles of modern educational system of Ukraine]. Pedahohichnyi poshuk Pedagogical search, issue 2, 12-15 [in Ukrainian]. 
8. Antonova, O.Ye. (2015). Akmeolohichnyi pidkhid do vyznachennia sutnosti obdarovanosti [Acmeological approach to determining the essence of talent]. Problemy osvity - Problems of education, issue 84, 36-40 [in Ukrainian].

9. Vintiuk, Yu.V. (2017). Pidhotovka maibutnikh fakhovykh psykholohiv: akmeolohichnyi pidkhid [Training of future professional psychologists: acmeological approach]. Molodyi vchenyiYoung scientist, 7, 267-271 [in Ukrainian].

10. Livshun, O.V. (2009). Akmeolohichni osoblyvosti profesiinoi hotovnosti maibutnoho vchytelia [Acmeological features of professional readiness of the future teacher]. Pedahohichni nauky - Pedagogical sciences, part 2, 79-81 [in Ukrainian].

11. Aseev, V.G. (2010). Motivatsiya uchebnoy deyatelnosti i formirovanie lichnosti [Motivation of educational activity and formation of personality]. Moscow: Akademiya [in Russian].

12. Perez, Y. \& Poole, P. (2019). Making language real: developing communicative and professional competences through global simulation. Simulation \& Gaming, Vol. 50, issue 6, 725-753 [in English]. 